\title{
Kemampuan Ruang Terbuka Hijau Publik dalam Berkontribusi Meresapkan Genangan Air Hujan di Surakarta
}

\author{
Agnes Laras Kusumastuti ${ }^{a}$, Galing Yudana ${ }^{b}$, Erma Fitria Rini ${ }^{c}$ \\ a Mahasiswi Perencanaan Wilayah dan Kota, Universitas Negeri Sebelas Maret (UNS) Surakarta, Indonesia \\ ${ }^{b}$ Dosen Perencanaan Wilayah dan Kota, Universitas Negeri Sebelas Maret (UNS) Surakarta, Indonesia \\ c Dosen Perencanaan Wilayah dan Kota, Universitas Negeri Sebelas Maret (UNS) Surakarta, Indonesia \\ E-mail Korespondensi: agneslaras07@gmail.com
}

\begin{abstract}
Kota Surakarta memiliki 283 Ha Ruang Terbuka Hijau (RTH) Publik yang terdiri dari 637 unit RTH. Salah satu fungsi ekologis RTH Publik adalah sebagai resapan air. Fenomea yang terjadi saat ini seringkali terjadi genangan pada berbagai jenis RTH publik pada saat hujan turun. Kondisi tersebut mengganggu aktivitas yang terjadi di dalamnya karena selain memiliki fungsi ekologis, ruang terbuka hijau juga memiliki fungsi sosial, ekonomi, dan estetika. Tujuan penelitian ini adalah untuk mengetahui tingkat kemampuan ruang terbuka hijau publik di Surakarta dalam mereduksi genangan air. Penelitian ini dilakukan menggunakan metode kuantitatif dengan teknik analisis skoring dan overlay. Analisis dilakukan dengan memberi skor pada 7 variabel yaitu karakteristik kawasan dan tutupan lahan, jenis vegetasi, tekstur tanah, jenis tanah, kelerengan, curah hujan, dan teknologi resapan dengan bobot 1 pada masing-masing variabel. Hasil skoring diklasifikasikan menjadi 3 klasifikasi dengan tingkat kemampuan tinggi, tingkat kemampuan sedang, dan tingkat kemampuan rendah. Untuk mengetahui hasilnya secara spasial, dilakukan dengan overlay melalui software ArcGIS. Dari hasil analisis didapatkan 20 unit RTH Publik memiliki tingkat kemampuan tinggi, 614 unit RTH Publik memiliki tingkat kemampuan sedang, dan 3 unit RTH Publik memiliki tingkat kemampuan rendah.Tingkat kemampuan Ruang Terbuka Hijau (RTH) Publik tersebut tersebar secara merata di 5 Kecamatan di Surakarta. Hasil penelitian ini menunjukkan bahwa tingkat kemampuan ruang terbuka hijau publik di Surakarta dalam mereduksi genangan air sebesar $171.531 \mathrm{~m}^{3}$ / Tahun atau sebesar 67.34\% dari kapasitas maksimumnya sehingga masih perlu ditingkatkan.
\end{abstract}

Keywords: limpasan air; resapan air; ruang terbuka hijau; genangan

How to cite (APA 6th Style):

Kusumastuti, AL., Yudana, Galing., Rini, Erma Fitria. (2020). Kemampuan Ruang Terbuka Hijau Publik dalam Berkontribusi Meresapkan Genangan Air Hujan di Surakarta, 1(1), 20-30. doi: 10.26418/uniplan.v1i1.43044

\section{PENDAHULUAN}

Perkembangan kota sering dikaitkan dengan perkembangan lahan terbangun. Seiring bertambahnya jumlah penduduk dan adanya proses urbanisasi, bertambah pula kebutuhan lahan untuk kebutuhan sosial dan ekonomi dalam suatu perkotaan (Prianggoro, 2015). Proses perkembangan (ekspansi) lahan terbangun yang terjadi tanpa adanya kontrol akan berakibat pada hilangnya fungsi lahan dan memunculkan permasalahan lingkungan (Zahrotunisa, 2017). Salah satu bentuk lahan yang terus berkurang akibat adanya ekspansi lahan terbangun adalah Ruang Terbuka Hijau (RTH) Publik. Ruang Terbuka Hijau (RTH) memiliki 4 fungsi yaitu fungsi estetika, fungsi sosisal, fungsi ekonomi, dan fungsi ekologis. Dengan adanya ekspansi lahan terbangun, dampak yang ditimbulkan pada Ruang Terbuka Hijau (RTH) Publik adalah fungsi ekologis. Dalam Peraturan Menteri Pekerjaan Umum No.5 Tahun 2008 tentang Pedoman Penyediaan dan Pemanfaatan Ruang Terbuka Hijau di Kawasan Perkotaan bahwa ruang terbuka hijau di kawasan perkotaan dapat berfungsi sebagai resapan air yang menjadi penentu keseimbangan lingkungan hidup dan lingkungan binaan dalam suatu rencana tata ruang (Samsudi, 2010). 
Kota Surakarta merupakan kota dengan pertumbuhan yang pesat. Dalam Rencana Tata Ruang Wilayah Kota Surakarta 2011-2031, pengembangan ruang terbuka hijau ditargetkan mencapai 30\% atau sebesar $882.04 \mathrm{Ha}$. Pengggunaan lahan di Surakarta dari tahun ke tahun terus mengalami penambahan luas. Berdasarkan data dari Badan Pertanahan Nasional (BPN) Kota Surakarta dalam Kota Surakarta Dalam Angka, luas lahan terbangun Kota Surakarta tahun 2008 seluas $80.68 \%$ dari total luas lahan di Kota

Surakarta. Sedangkan di tahun 2018 luas lahan terbangun meningkat menjadi 82.35\%. Peningkatan luas lahan terbangun tersebut karena kebutuhan akan perumahan, industri dan kegiatan perusahaan. Peningkatan luas lahan terbangun tersebut berbanding terbalik dengan keberadaan lahan non terbangun khususnya ruang terbuka hijau publik. Sebagai contoh pada tahun 2008 luas taman kota di Kota Surakarta sebesar 31.6 Ha sedangkan pada tahun 2018 menjadi 12.11 Ha (Kota Surakarta Dalam Angka Tahun 2013 dan 2019).

Fenomena yang terjadi pada Ruang Terbuka Hijau (RTH) Publik di Surakarta adalah adanya genangan air saat hujan turun di beberapa lokasi. Kondisi tersebut mengganggu aktivitas yang terjadi di dalamnya. Sebagai contoh pada perempatan Jalur pejalan kaki Jl. Ahmad Yani, Jebres; Jl. Urip Sumuharjo, Jebres; J. Menteri Supeno, Manahan; serta JI. KH Samanhudi, Purwosari. Selain pada ruas ruas jalan, genangan juga terjadi pada area-area terbuka seperti pada median tengah jalan dan taman-taman. Dalam kondisi seperti ini, keberadaan ruang terbuka hijau publik dalam fungsinya sebagai tempat meresapnya air terutama air hujan sangat diperlukan sebagai salah satu cara mengatasi permasalahan tersebut. Penelitian ini ingin mengetahui bagaimana tingkat kemampuan Ruang Terbuka Hijau (RTH) Publik di Surakarta dalam mengatasi permasalah genangan tersebut.

\section{DATA DAN METODE}

\subsection{Ruang Terbuka Hijau Publik di Surakarta}

Di Surakarta pengelolaan dan penyelenggaraan ruang terbuka hijau publik menjadi tupoksi Dinas Lingkungan Hidup Kota Surakarta. Berdasarkan pengukuran yang dilakukan oleh Dinas Lingkungan Hidup Kota Surakarta pada tahun 2019, luas ruang terbuka hijau di Surakarta mencapai 3.729.713,81 $\mathrm{m}^{2}(372,97$ $\mathrm{Ha}$ ). Dari total luas ruang terbuka hijau tersebut, $2.829 .950 \mathrm{~m}^{2}(283 \mathrm{Ha})$ ruang terbuka hijau merupakan ruang terbuka hijau publik. Persebaran ruang terbuka hijau publik di Surakarta dapat dilihat pada Gambar 1. Luasan ruang terbuka hijau publik di Kota Surakarta tersebar dalam 637 unit yang tersebar dalam 13 jenis RTH yang berdasarkan kondisinya, $78 \%$ kondisi ruang terbuka hijau publik tersebut dapat dikatakan dalam kondisi baik, ditinjau dari vegetasi maupun fasilitas didalamnya.

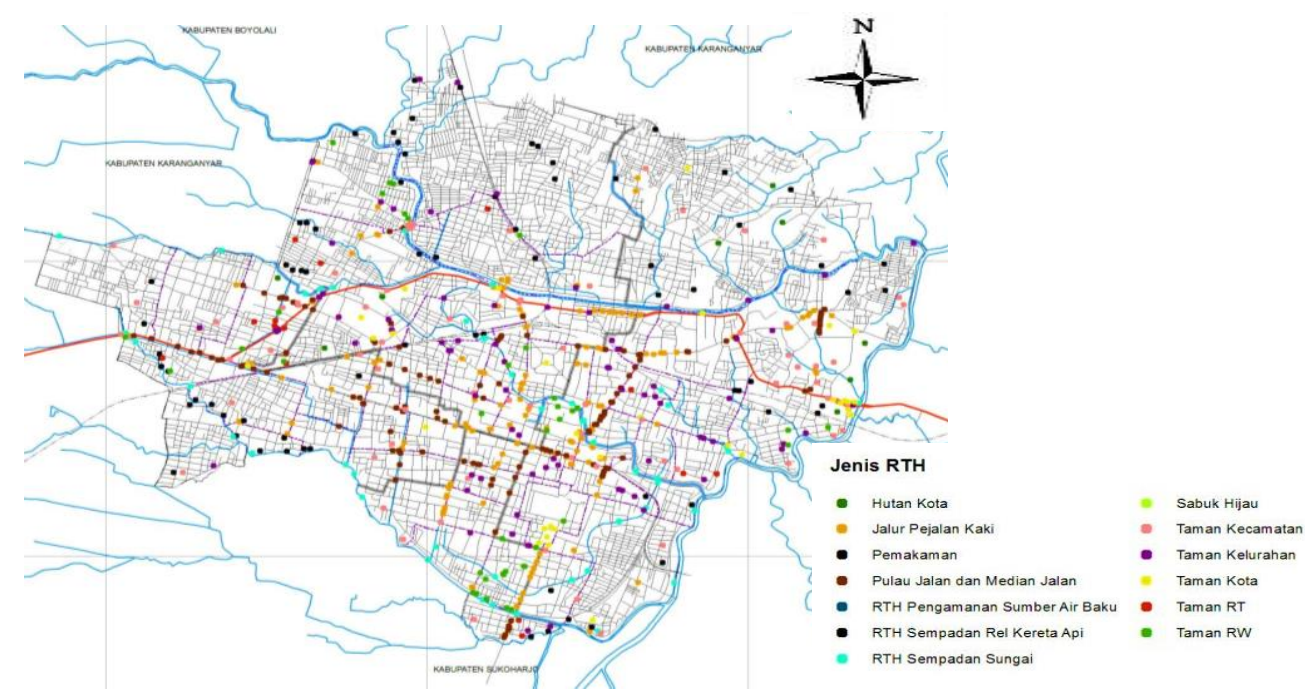

Gambar 1. Persebaran Ruang Terbuka Hijau Publik di Surakarta 


\subsection{Karakteristik Kawasan dan Tutupan Lahan}

Data karakteristik kawasan dan tutupan lahan digunakan untuk penentuan koefisien limpasan pada unit RTH yang kemudian besarnya koefisien limpasan akan berpengaruh pada nilai skoring. Koefisien limpasan pada suatu area dilambangkan dengan notasi $C$ dan dinyatakan dengan nilai antara 0 sampai 1 . Semakin besar nilai $\mathrm{C}$ maka kemampuan suatu permukaan tanah dalam meresapkan air semakin rendah (Sarbidi, 2012). Karakteristik kawasan digunakan untuk menilai koefisien limpasan pada unit RTH yang homogen dan memiliki area yang luas, yaitu RTH Sempadan Rel, RTH Sempadan Sungai, Pengamanan Sumber Air Baku, dan Pemakaman. Sedangkan tutupan lahan digunakan untuk menilai koefisien limpasan pada unit RTH yang berukuran kecil dan memiliki bentuk yang beragam. Berikut pada Tabel 1 merupakan data karakteristik kawasan dan pada Tabel 2 merupakan data tutupan lahan yang didapatkan.

Tabel 1. Karakteristik Kawasan pada RTH Publik di Surakarta

\begin{tabular}{|c|c|c|c|c|}
\hline Karakteristik Kawasan & $\begin{array}{c}\text { RTH } \\
\text { Sempadan } \\
\text { Rel }\end{array}$ & $\begin{array}{c}\text { RTH } \\
\text { Sempadan } \\
\text { Sungai }\end{array}$ & $\begin{array}{c}\text { RTH } \\
\text { Pengaman } \\
\text { Sumber Air } \\
\text { Baku }\end{array}$ & $\begin{array}{c}\text { RTH } \\
\text { Pemakaman }\end{array}$ \\
\hline $\begin{array}{c}\text { Permukiman satu rumah } \\
\text { (Koefisien limpasan = 0.3-0.5) }\end{array}$ & - & 3 & - & 9 \\
\hline $\begin{array}{c}\text { Permukiman banyak rumah terpisah } \\
\text { (Koefisien limpasan = 0.4-0.6) }\end{array}$ & - & 18 & 1 & 41 \\
\hline $\begin{array}{c}\text { Banyak rumah rapat } \\
\text { (Koefisien limpasan = 0.6-0.75) }\end{array}$ & - & 21 & - & 6 \\
\hline $\begin{array}{c}\text { Perdagangan kota } \\
\text { (Koefisien limpasan =0.7-0.95) }\end{array}$ & - & - & - & 1 \\
\hline $\begin{array}{c}\text { Industri ringan } \\
\text { (Koefisien limpasan =0.5-0.8) }\end{array}$ & - & - & - & 2 \\
\hline $\begin{array}{c}\text { Halaman Jalan KA } \\
\text { (Koefisien limpasan = 0.2-0.35) }\end{array}$ & 10 & - & - & 2 \\
\hline $\begin{array}{c}\text { Lapangan kuburan } \\
\text { (Koefisien limpasan = 0.1-0.25) }\end{array}$ & - & - & - & 1 \\
\hline $\begin{array}{c}\text { Lahan tidak terpelihara } \\
\text { (Koefisien limpasan = 0.1-0.3) }\end{array}$ & - & 5 & - & $\mathbf{6 2}$ \\
\hline TOTAL & $\mathbf{1 0}$ & $\mathbf{4 7}$ & $\mathbf{1}$ & 2 \\
\hline
\end{tabular}

Tabel 2. Tutupan Lahan pada RTH Publik di Surakarta

\begin{tabular}{|c|c|c|c|c|c|c|c|c|c|}
\hline Tutupan Lahan & 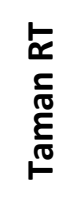 & 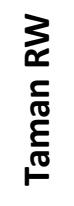 & 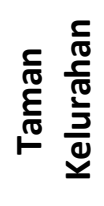 & 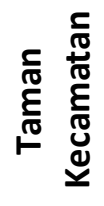 & 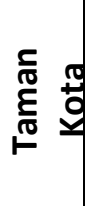 & 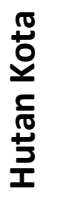 & 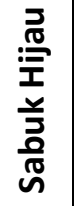 & $\begin{array}{l}\frac{\sqrt{0}}{\sqrt{0}} \\
\frac{\vec{J}}{3} \\
\frac{\pi}{3}\end{array}$ & 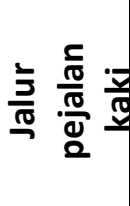 \\
\hline $\begin{array}{l}\text { Halaman Berumput tanah pasir } \\
\text { (Koefisien limpasan = 0.05-0.2) }\end{array}$ & 10 & 32 & 55 & 41 & 14 & - & - & 79 & 1 \\
\hline $\begin{array}{l}\text { Halaman berumput tanah pasir padat } \\
\text { (Koefisien limpasan }=0.13-0.35 \text { ) }\end{array}$ & 2 & 2 & 7 & 10 & 14 & 9 & - & 23 & - \\
\hline $\begin{array}{c}\text { Batu bata dan batako } \\
\text { (Koefisien limpasan }=0.7-0.85 \text { ) }\end{array}$ & - & 3 & 1 & 2 & 2 & - & - & 5 & 121 \\
\hline $\begin{array}{c}\text { Aspal beton } \\
\text { (Koefisien limpasan }=0.75-0.95 \text { ) }\end{array}$ & 2 & 2 & 15 & 17 & - & - & 1 & 20 & 23 \\
\hline
\end{tabular}




\begin{tabular}{|c|c|c|c|c|c|c|c|c|c|}
\hline $\begin{array}{c}\text { Atap rumah } \\
\text { (Koefisien limpasan }=0.7-0.95)\end{array}$ & - & - & 1 & 3 & - & - & - & - & - \\
\hline TOTAL & $\mathbf{1 4}$ & $\mathbf{3 9}$ & $\mathbf{7 9}$ & $\mathbf{7 3}$ & $\mathbf{3 0}$ & $\mathbf{9}$ & $\mathbf{1}$ & $\mathbf{1 2 7}$ & $\mathbf{1 4 5}$ \\
\hline
\end{tabular}

\subsection{Jenis Vegetasi}

Menurut Wibowo (2006), meresapnya air ke dalam tanah melalui dua tahapan yaitu infiltrasi dan perlokasi. Dalam prosesnya, infiltrasi dipengaruhi oleh vegetasi yang akan semakin besar daya infiltrasinya jika suatu permukaan tertutup oleh tumbuh tumbuhan (Wibowo M. , 2006). Jenis vegetasi pada ruang terbuka hijau publik di Surakarta di dominasi pleh jenis semak belukar yang memiliki tingkat kemampuan dalam meresapkan air agak tinggi. Semak belukar dicirikan dengan adanya vegetasi pada lahan kering dengan tingkat kerapatan sedang hingga jarang sesuai dengan SNI 7645:2010 tentang klasifikasi penutup lahan. Pada tabel 3 berikut merupakan data jenis vegetasi yang didapatkan.

Tabel 3. Jumlah RTH Publik berdasarkan Jenis Vegetasi

\begin{tabular}{|c|c|c|c|c|c|c|c|c|c|c|c|c|c|}
\hline $\begin{array}{c}\text { Jenis } \\
\text { Vegetasi }\end{array}$ & 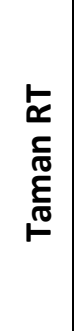 & 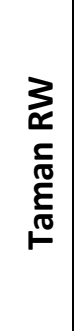 & 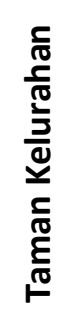 & 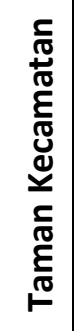 & 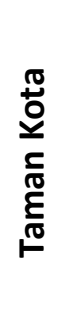 & 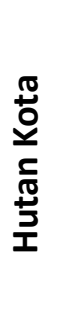 & 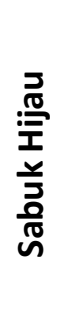 & $\begin{array}{l}\frac{\sqrt{\pi}}{\pi} \\
\frac{\pi}{\sqrt{2}} \\
\frac{\pi}{3}\end{array}$ & 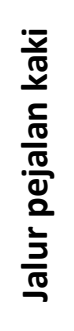 & 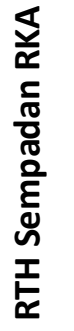 & 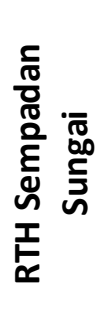 & 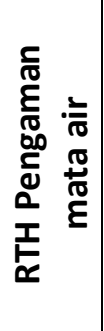 & 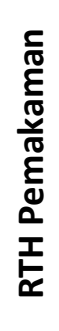 \\
\hline Hutan & - & - & & & 1 & 5 & - & - & - & - & - & - & - \\
\hline $\begin{array}{l}\text { Semak } \\
\text { Belukar }\end{array}$ & 9 & 37 & 72 & 41 & 22 & 4 & 1 & 119 & 23 & 2 & 19 & 1 & 57 \\
\hline Ladang Kebun & 1 & 1 & - & - & - & - & - & - & - & & 6 & - & 3 \\
\hline $\begin{array}{c}\text { Tidak } \\
\text { Bervegetasi }\end{array}$ & 4 & 1 & 7 & 32 & 7 & - & - & 8 & 122 & 8 & 22 & - & 2 \\
\hline TOTAL & 14 & 39 & 79 & 73 & 30 & 9 & 1 & 127 & 145 & 10 & 47 & 1 & 62 \\
\hline
\end{tabular}

\subsection{Tekstur Tanah}

Tekstur tanah diamati dengan cara kualitatif dengan membandingan ciri ciri jenis tekstur tanah pada setiap RTH. Jika tanah berwarna coklat seperti yang ada pada teori segitiga tanah maka tanah termasuk jenis lempung, namun jika cenderung berwarna abu atau gelap maka termasuk jenis pasir. Pada Tabel 4. diketahui bahwa dominasi tekstur tanah berupa lempung berpasir yang memiliki tingkat kemampuan sedang dalam mereduksi limpasan air yang ditemui pada 10 jenis RTH.

Tabel 4. Jumlah RTH Publik berdasarkan Tekstur Tanah

\begin{tabular}{|c|c|c|c|c|c|c|c|c|c|c|c|c|c|}
\hline $\begin{array}{l}\text { Tekstur } \\
\text { Tanah }\end{array}$ & $\begin{array}{l}\text { tr } \\
\frac{1}{\pi} \\
\frac{E}{\sigma} \\
⺊\end{array}$ & 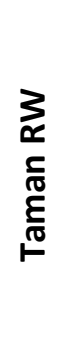 & 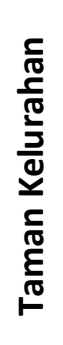 & 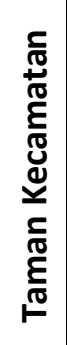 & 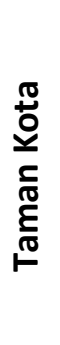 & 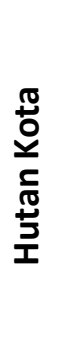 & 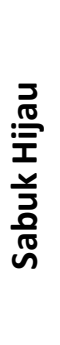 & $\begin{array}{l}\frac{2}{\pi} \\
\frac{\pi}{2} \\
\frac{\pi}{3} \\
\frac{\pi}{2}\end{array}$ & 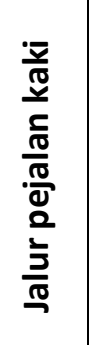 & 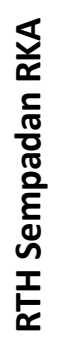 & 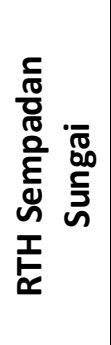 & 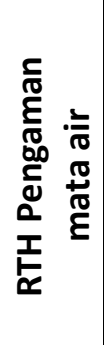 & 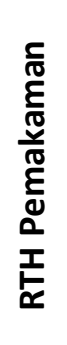 \\
\hline Pasir & 1 & 5 & 2 & 2 & 1 & - & 1 & 95 & 143 & 10 & - & 1 & 1 \\
\hline $\begin{array}{c}\text { Pasir } \\
\text { berlempung }\end{array}$ & 3 & 8 & 4 & 7 & 3 & - & - & 7 & & & 18 & - & - \\
\hline
\end{tabular}




\begin{tabular}{|c|c|c|c|c|c|c|c|c|c|c|c|c|c|}
\hline $\begin{array}{c}\text { Lempung } \\
\text { berpasir }\end{array}$ & 10 & 25 & 68 & 59 & 26 & 8 & - & 17 & 2 & - & 29 & - & 61 \\
\hline $\begin{array}{c}\text { Lempung } \\
\text { berpasir halus }\end{array}$ & - & 1 & 3 & - & - & - & - & - & - & - & - & - & - \\
\hline Lempung & - & - & 2 & 5 & - & 1 & - & 8 & - & - & - & - & - \\
\hline TOTAL & $\mathbf{1 4}$ & $\mathbf{3 9}$ & $\mathbf{7 9}$ & $\mathbf{7 3}$ & $\mathbf{3 0}$ & $\mathbf{9}$ & $\mathbf{1}$ & $\mathbf{1 2 7}$ & $\mathbf{1 4 5}$ & $\mathbf{1 0}$ & $\mathbf{4 7}$ & $\mathbf{1}$ & $\mathbf{6 2}$ \\
\hline
\end{tabular}

\subsection{Jenis Tanah}

Beberapa faktor yang mempengaruhi kemampuan suatu area dalam meresapkan air, salah satunya dipengaruhi oleh kondisi fisik dasar yaitu tekstur tanah, kelerengan, dan curah hujan (Resubun, 2015).Jenis tanah didapatkan dengan survey data sekunder melalui peta geologi. Jenis tanah pada Kota Surakarta terbagi menjadi 2 jenis yaitu alluvial dan latosol. Dominasi RTH Publik dengan jenis tanah alluvial sebanyak 625 unit dan sisanya sebanyak 28 unit memiliki jenis tanah latosol. Rincian Jenis Tanah dapat dilihat pada Tabel 5.

Tabel 5. Jumlah RTH Publik berdasarkan Jenis Tanah

\begin{tabular}{|c|c|c|c|c|c|c|c|c|c|c|c|c|c|}
\hline Jenis Tanah & 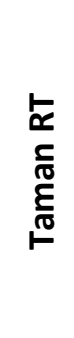 & 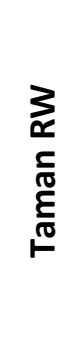 & 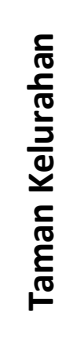 & 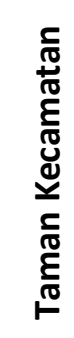 & 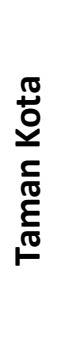 & 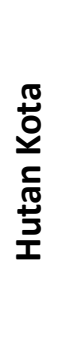 & 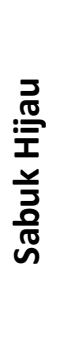 & $\begin{array}{l}\frac{\sqrt{0}}{\sqrt{0}} \\
\frac{\vec{J}}{\vec{J}} \\
\frac{\pi}{\overrightarrow{3}}\end{array}$ & 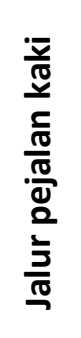 & 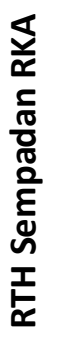 & 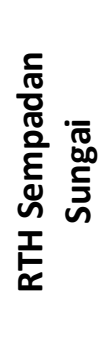 & 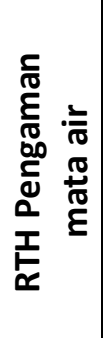 & 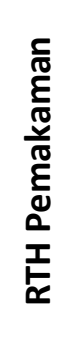 \\
\hline Alluvial & 14 & 38 & 79 & 68 & 29 & 6 & 1 & 126 & 143 & 10 & 44 & 1 & 51 \\
\hline Latosol & - & 1 & - & 5 & 1 & 3 & - & 1 & 3 & - & 3 & - & 11 \\
\hline TOTAL & 14 & 39 & 79 & 73 & 30 & 9 & 1 & 127 & 145 & 10 & 47 & 1 & 62 \\
\hline
\end{tabular}

\subsection{Curah Hujan}

Curah hujan Kota Surakarta terbagi menjadi 2 kelas yang kondisinya tidak jauh berbeda. Dari 652 unit RTH di Kota Surakarta, 549 diantaranya masuk dalam kelas 1750-2250 mm/th. Sedangkan 3 sisanya masuk dalam kelas 1500-1750 mm/th. Skoring dilakukan dengan mengambil nilai batas atas curah hujan eksisting sehingga dapat masuk dalam kategori yang telah ditentukan. Sebaran RTH berdasarkan curah hujan dapat dilihat pada Tabel 6 .

Tabel 6. Jumlah RTH Publik berdasarkan Curah Hujan

\begin{tabular}{|c|c|c|c|c|c|c|c|c|c|c|c|c|c|}
\hline $\begin{array}{c}\text { Curah Hujan } \\
(\mathrm{mm} / \mathrm{th})\end{array}$ & 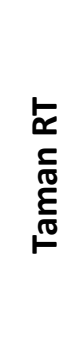 & 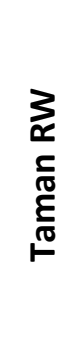 & $\begin{array}{l}\frac{5}{0} \\
\frac{0}{\pi} \\
\frac{0}{3} \\
\frac{0}{d} \\
\frac{1}{10} \\
\frac{c}{\pi} \\
\frac{5}{0}\end{array}$ & 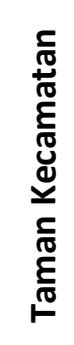 & 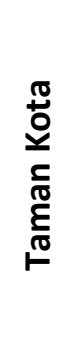 & 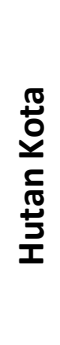 & 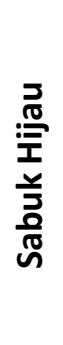 & $\begin{array}{l}\frac{5}{\pi} \\
\frac{\pi}{\sqrt{2}} \\
\frac{\pi}{3} \\
\frac{\pi}{2}\end{array}$ & 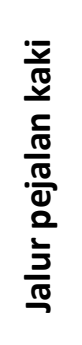 & 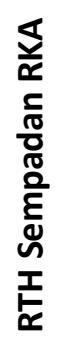 & 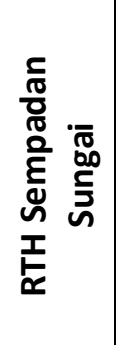 & 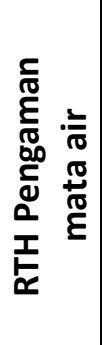 & 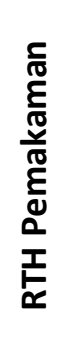 \\
\hline $1500-1750$ & - & - & 1 & 1 & - & - & - & - & - & - & - & - & 1 \\
\hline $1750-2250$ & 14 & 39 & 78 & 72 & 30 & 9 & 1 & 127 & 145 & 10 & 47 & 1 & 61 \\
\hline TOTAL & 14 & 39 & 79 & 73 & 30 & 9 & 1 & 127 & 145 & 10 & 47 & 1 & 62 \\
\hline
\end{tabular}




\subsection{Kelerengan}

Data kemiringan lahan didapatkan melalui survey data sekunder. Berdasarkan data yang didapatkan, Kota Surakarta diklasifikasikan menjadi 3 golongan kelerengan yaitu kemiringan lahan rendah $0-8 \%$, kemiringan lahan sedang 8-15\%, dan kemiringan lahan tinggi 15-25\%. Semakin tinggi kemiringan lereng suatu lahan maka semakin rendah kemampuannya dalam meresapkan air. Sebaran RTH berdasarkan tingkat kelerengan dapat dilihat pada Tabel 7.

Tabel 7. Jumlah RTH Publik berdasarkan Besar Kelerengan

\begin{tabular}{|c|c|c|c|c|c|c|c|c|c|c|c|c|c|}
\hline Kelerengan & $\begin{array}{l}\text { - } \\
\frac{c}{\pi} \\
\frac{E}{\sigma} \\
\stackrel{\sigma}{\sigma}\end{array}$ & 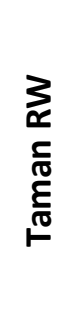 & 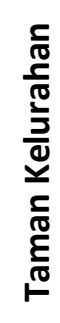 & 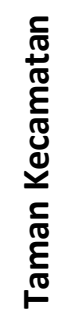 & 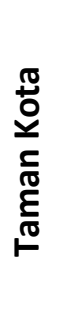 & 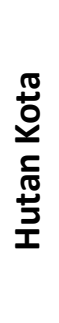 & 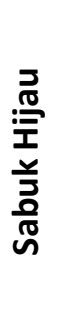 & 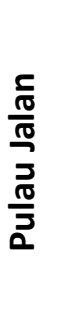 & 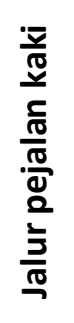 & 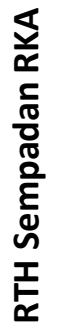 & 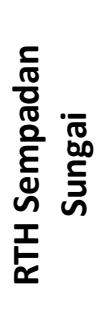 & 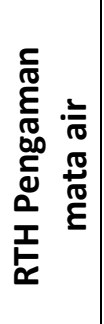 & 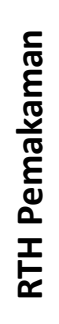 \\
\hline $0 \%-8 \%$ & 10 & 29 & 57 & 43 & 17 & 3 & 1 & 100 & 101 & 5 & 38 & - & 26 \\
\hline $8 \%-15 \%$ & 4 & 10 & 16 & 23 & 8 & 6 & - & 27 & 42 & 5 & 3 & - & 31 \\
\hline $15 \%-25 \%$ & - & - & 6 & 7 & 5 & - & - & - & 2 & - & 6 & 1 & 5 \\
\hline TOTAL & 14 & 39 & 79 & 73 & 30 & 9 & 1 & 127 & 145 & 10 & 47 & 1 & 62 \\
\hline
\end{tabular}

\subsection{Teknologi Resapan}

Teknologi konservasi ditujukan untuk meningkatkan resapan air ke dalam tanah. ketersediaan teknologi resapan seperti sumur resapan, kolam konservasi air hujan dan lubang biopori juga akan berpengaruh pada kemampuan meresapkan air (Untari, 2012). Berdasarkan data yang telah dihimpun melalui pengamatan, survey data sekunder DLH Kota Surakarta, dan kajian literature didapatkan beberapa titik RTH yang memiliki teknologi resapan seperti pada tabel 8 berikut.

Tabel 8. Ketersediaan Teknologi Resapan pada RTH Publik di Surakarta

\begin{tabular}{|c|c|c|}
\hline Jenis Teknologi Resapan & Jumlah & Lokasi RTH \\
\hline Sumur Resapan Dalam & 3 & $\begin{array}{c}\text { Taman Balaikota; Taman } \\
\text { Kelurahan Kerten; } \\
\text { Lapangan Jalan Apel, } \\
\text { Jajar }\end{array}$ \\
\hline Biopori & 2 & $\begin{array}{c}\text { Taman Sekartaji, Taman } \\
\text { Balekambang }\end{array}$ \\
\hline
\end{tabular}

\subsection{Metode Analisis}

Pendekatan yang dilakukan dalam penelitian ini adalah pendekatan deduktif dengan jenis penelitian kuantitatif. Metode pengumpulan data dilakukan melalui survey data primer dan survey data sekunder. Survey data primer didlakukan dengan observasi pada 637 unit Ruang Terbuka Hijau (RTH) Publik, sedangkan survey data sekunder dilakukan dengan mencari data kepada instansi/dinas terkait dalam hal ini Dinas Lingkungan Hidup Kota Surakarta. Setiap unit RTH dinilai dengan 7 variabel dengan bobot 1 pada masing-masing variabel seperti pada Tabel 1 . Sehingga didapatkan skor tertinggi yang memungkinkan adalah 7. Hasil skoring diklasifikasikan menjadi 3 kategori dengan tingkat kemampuan rendah 1.09-3.06, tingkat kemampuan sedang 3.07-5.07, dan kemampuan tinggi 5.08-7. 
Tabel 9. Parameter dan Nilai pada Setiap Variabel

\begin{tabular}{|c|c|c|c|c|}
\hline Variabel & Bobot & Kelas & $\begin{array}{c}\text { Kemampuan meresapkan } \\
\text { air }\end{array}$ & Nilai \\
\hline \multirow{5}{*}{$\begin{array}{c}\text { Tekstur } \\
\text { Tanah }\end{array}$} & \multirow[t]{5}{*}{1} & \multirow{5}{*}{$\begin{array}{c}\text { Pasir } \\
\text { Pasir berlempung } \\
\text { Lempung berpasir } \\
\text { Lempunt berpasir halus } \\
\text { Lempung }\end{array}$} & \multirow{5}{*}{$\begin{array}{c}\text { Sangat Tinggi } \\
\text { Tinggi } \\
\text { Sedang } \\
\text { Rendah } \\
\text { Sangat Rendah }\end{array}$} & 1 \\
\hline & & & & 0.8 \\
\hline & & & & 0.6 \\
\hline & & & & 0.4 \\
\hline & & & & 0.2 \\
\hline \multirow{5}{*}{$\begin{array}{l}\text { Batuan } \\
\text { Penyusun }\end{array}$} & \multirow[t]{5}{*}{1} & \multirow{5}{*}{$\begin{array}{c}\text { Kompleks Entisol } \\
\text { Andisol } \\
\text { Inceptisol / Latosol } \\
\text { Kompleks Ultisol } \\
\text { Tanah Alluvial }\end{array}$} & \multirow{5}{*}{$\begin{array}{l}\text { Sangat Tinggi } \\
\text { Tinggi } \\
\text { Sedang } \\
\text { Rendah } \\
\text { Sangat Rendah }\end{array}$} & 1 \\
\hline & & & & 0.8 \\
\hline & & & & 0.6 \\
\hline & & & & 0.4 \\
\hline & & & & 0.2 \\
\hline \multirow[t]{5}{*}{ Kelerengan } & \multirow[t]{5}{*}{1} & $<8 \%$ & \multirow{5}{*}{$\begin{array}{l}\text { Sangat Tinggi } \\
\text { Tinggi } \\
\text { Sedang } \\
\text { Rendah } \\
\text { Sangat Rendah }\end{array}$} & 1 \\
\hline & & $8-15 \%$ & & 0.8 \\
\hline & & $15-25 \%$ & & 0.6 \\
\hline & & $25-40 \%$ & & 0.4 \\
\hline & & $>40 \%$ & & 0.2 \\
\hline \multirow[t]{5}{*}{ Curah Hujan } & \multirow[t]{5}{*}{1} & $>3000 \mathrm{~mm} / \mathrm{Th}$ & \multirow{5}{*}{$\begin{array}{c}\text { Sangat Tinggi } \\
\text { Tinggi } \\
\text { Sedang } \\
\text { Rendah } \\
\text { Sangat Rendah }\end{array}$} & 1 \\
\hline & & 2000-3000 mm/Th & & 0.8 \\
\hline & & $1000-2000 \mathrm{~mm} / \mathrm{Th}$ & & 0.6 \\
\hline & & $500-1000 \mathrm{~mm} / \mathrm{Th}$ & & 0.4 \\
\hline & & $<500 \mathrm{~mm} / \mathrm{Th}$ & & 0.2 \\
\hline \multirow{5}{*}{$\begin{array}{c}\text { Jenis } \\
\text { Vegetasi }\end{array}$} & \multirow[t]{5}{*}{1} & Hutan & \multirow{5}{*}{$\begin{array}{c}\text { Sangat Tinggi } \\
\text { Tinggi } \\
\text { Sedang } \\
\text { Rendah } \\
\text { Sangat Rendah }\end{array}$} & 1 \\
\hline & & Semak Belukar & & 0.8 \\
\hline & & Ladang Kebun & & 0.6 \\
\hline & & Sawah Rawa & & 0.4 \\
\hline & & Tidak Bervegetasi & & 0.2 \\
\hline \multirow{2}{*}{$\begin{array}{l}\text { Teknologi } \\
\text { Resapan }\end{array}$} & \multirow[t]{2}{*}{1} & Ada & \multirow{2}{*}{$\begin{array}{r}\text { Tinggi } \\
\text { Rendah }\end{array}$} & 1 \\
\hline & & Tidak & & 0 \\
\hline \multirow{16}{*}{$\begin{array}{l}\text { Karakteristik } \\
\text { Kawasan } \\
\text { Sekitar dan } \\
\text { Tutupan } \\
\text { Lahan }\end{array}$} & \multirow[t]{16}{*}{1} & \multicolumn{3}{|c|}{ Penilaian menggunakan karakteristik kawasan } \\
\hline & & $0.70-0.95$ & \multirow{11}{*}{$\begin{array}{c}\text { Semakin kecil koefisien } \\
\text { maka semakin tinggi } \\
\text { kemampuan meresapkan } \\
\text { air }\end{array}$} & 0.09 \\
\hline & & $0.60-0.90$ & & 0.18 \\
\hline & & $0.50-0.80$ & & 0.27 \\
\hline & & $0.60-0.75$ & & 0.36 \\
\hline & & $0.50-0.70$ & & 0.45 \\
\hline & & $0.40-0.60$ & & 0.54 \\
\hline & & $0.30-0.50$ & & 0.63 \\
\hline & & $0.25-0.40$ & & 0.72 \\
\hline & & $0.20-0.35$ & & 0.81 \\
\hline & & $0.10-0.30$ & & 0.90 \\
\hline & & $0.10-0.25$ & & 1 \\
\hline & & \multicolumn{3}{|c|}{ Penilaian menggunakan tutupan lahan } \\
\hline & & $0.75-0.95$ & Semakin kecil koefisien & 0.11 \\
\hline & & $0.70-0.95$ & maka semakin tinggi & 0.22 \\
\hline & & $0.70-0.85$ & kemampuan meresapkan & 0.33 \\
\hline
\end{tabular}




\begin{tabular}{|l|l|l|c|}
\hline & $0.25-0.35$ & air & 0.44 \\
\cline { 3 - 4 } & $0.18-0.22$ & & 0.55 \\
\cline { 3 - 4 } & $0.15-0.20$ & & 0.67 \\
\hline & $0.13-0.17$ & 0.78 \\
\cline { 3 - 4 } & $0.10-0.15$ & & 0.89 \\
\hline
\end{tabular}

Pada tiga tingkatan kelas tersebut diasumsikan bahwa batas atas kapasitar air yang dapat diserap oleh RTH adalah pada RTH yang memiliki tingkat kemampuan tinggi yaitu dapat meresapkan seluruh air hujan (100\%) yang jatuh sesuai dengan kapasitas maksimumnya yaitu $900 \mathrm{~m}^{3} / \mathrm{Ha} / T a h u n$ (Syamsir, 2017) dan batas terendah pada RTH yang memiliki tingkat kemampuan rendah diasumsikan sebesar $0 \%$. Sehingga didapatkan klasifikasi tingkat kemampuan rendah mampu meresapkan sebesar $0 \%-33.3 \%$, tingkat kemampuan sedang mampu meresapkan sebesar 33.4\%-66.6\% dan tingkat kemampuan tinggi dapat meresapkan sebesar $66.7 \%-100 \%$. Dalam perhitungan digunakan batas atas kelas yaitu Ruang Terbuka Hijau dengan kategori tingkat kemampuan rendah dinilai mampu meresapkan hingga $33.3 \%$ dari kemampuan seharusnya $900 \mathrm{~m}^{3} / \mathrm{Ha} / \mathrm{Tahun}$ yaitu sebesar $299 \mathrm{~m}^{3} / \mathrm{Ha} / \mathrm{Tahun}$. Ruang Terbuka Hijau dengan kategori tingkat kemampuan sedang dinilai mampu meresapkan hingga 66.6\% dari kemampuan seharusnya $900 \mathrm{~m}^{3} / \mathrm{Ha} /$ Tahun yaitu sebesar $599.4 \mathrm{~m}^{3} / \mathrm{Ha}$ /Tahun. Dan Ruang Terbuka Hijau dengan kategori tingkat kemampuan tinggi dinilai mampu meresapkan sebesar $100 \%$ dari $900 \mathrm{~m}^{3} / \mathrm{Ha} /$ Tahun.

Untuk mengetahui hasilnya secara spasial, dilakukan dengan teknik overlay menggunakan software ArcGIS. Overlay dilakukan dengan menggabungkan atribut pada setiap layer peta yang berisi informasi mengenai 7 variabel. Output yang dihasilkan yaitu peta persebaran ruang terbuka hijau publik di Surakarta dengan tingkat kemampuannya dalam mereduksi limpasan air.

\section{HASIL DAN PEMBAHASAN}

Analisis dilakukan pada 637 unit RTH Publik di Surakarta yang terdiri dari 13 Jenis RTH Publik. Dengan memberi skor pada setiap unit RTH berdasarkan parameter pada setiap variabel seperti pada Tabel 9. Didapatkan hasil skoring seperti pada Tabel 10.

Tabel 10.Hasil Skoring Variabel Kemampuan Meresapkan Air

\begin{tabular}{|c|c|c|c|}
\hline \multirow{2}{*}{ Jenis RTH } & \multicolumn{3}{|c|}{ Tingkat Kemampuan Mereduksi } \\
& Rendah & Sedang & Tinggi \\
\cline { 2 - 4 } & - & 14 & - \\
Taman RT & - & 39 & - \\
Taman RW & 4 & 75 & - \\
Taman Kelurahan & 13 & 60 & - \\
Taman Kecamatan & 1 & 28 & 1 \\
Taman Kota & - & 8 & 1 \\
Hutan Kota & - & 1 & - \\
Sabuk Hijau & - & 145 & - \\
Jalur Pejalan Kaki & 1 & 125 & 1 \\
Pulau Jalan dan Median Jalan & - & 10 & - \\
Sempadan Rel Kereta Api & 1 & 46 & - \\
Sempadan Sungai & - & 1 & - \\
RTH Pengamanan Sumber Air & & & \\
Baku/Mata Air & - & 62 & - \\
RTH Pemakaman & 20 & 614 & 3 \\
\hline TOTAL & &
\end{tabular}


Luas ruang terbuka hijau publik di Surakarta berdasarkan tingkat kemampuannya dalam mereduksi limpasan air dapat dlihat pada Tabel 11. Dengan rincian luas seperti pada Tabel 2 dan kemampuan RTH dalam menyerap air sebesar $900 \mathrm{~m}^{3} / \mathrm{Ha}$ /Tahun maka didapatkan besar kemampuan RTH Publik Kota Surakarta dalam mereduksi limpasan air hujan adalah $171.531 \mathrm{~m}^{3}$ / Tahun atau sebesar $67.34 \%$ dari kapasitas maksimumnya.

Tabel 11. Luas RTH Publik Surakarta berdasarkan Tingkat Kemampuan Mereduksi Limpasan Air

\begin{tabular}{|c|c|}
\hline Kategori & Luas $(\mathbf{H a})$ \\
\hline Tingkat kemampuan tinggi & 8.97 \\
\hline Tingkat kemampuan sedang & 271.37 \\
\hline Tingkat kemampuan rendah & 2.66 \\
\hline TOTAL & 283 \\
\hline
\end{tabular}

Kemudian dilakukan overlay menggunakan ArcGIS untuk mengetahui hasil analisis secara spasial. Overlay dilakukan dengan menggabungkan atribut peta masing-masing variabel. Ilustrasi proses overlay digambarkan seperti pada Gambar 2.

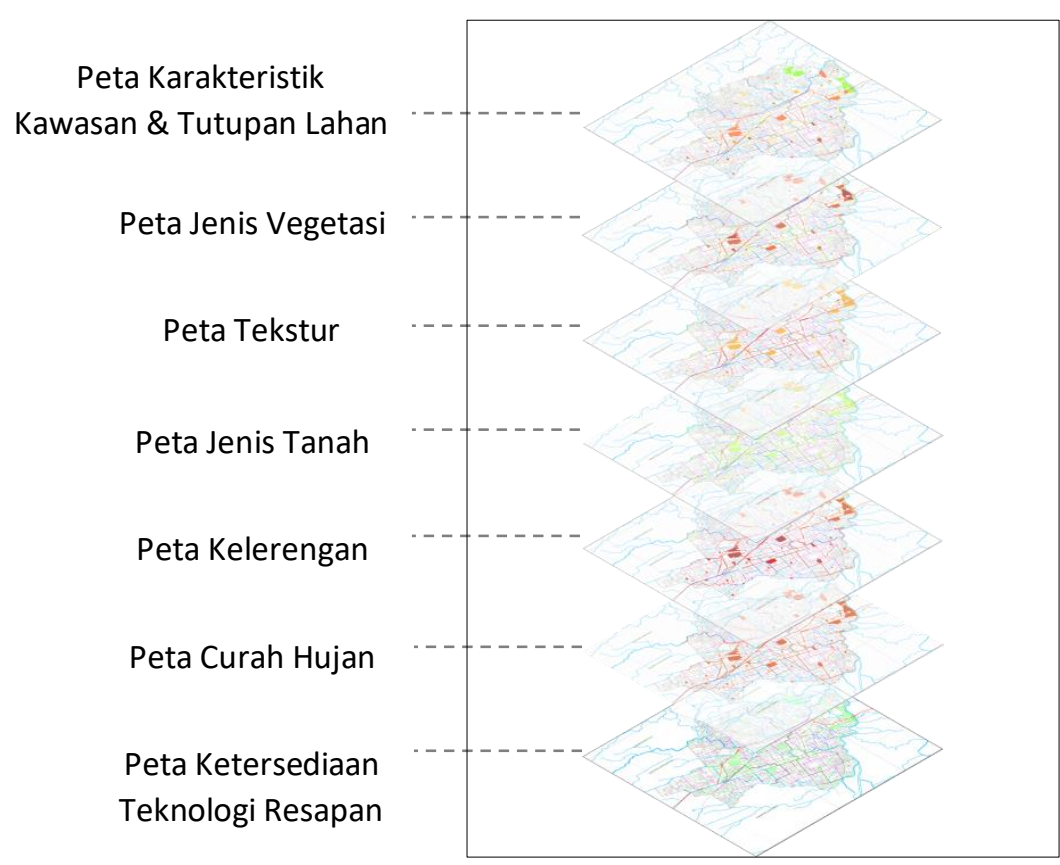

Gambar 2. Ilustrasi Proses Overlay

Sehingga dari hasil overlay didapatkan persebaran Ruang Terbuka Hijau Publik di Surakarta sesuai dengan tingkat kemampuannya dalam mereduksi limpasan air. Peta persebaran Tingkat Kemampuan Ruang Terbuka Hijau Publik di Surakarta dalam mereduksi limpasan air dapat dilihat pada Gambar 3. 

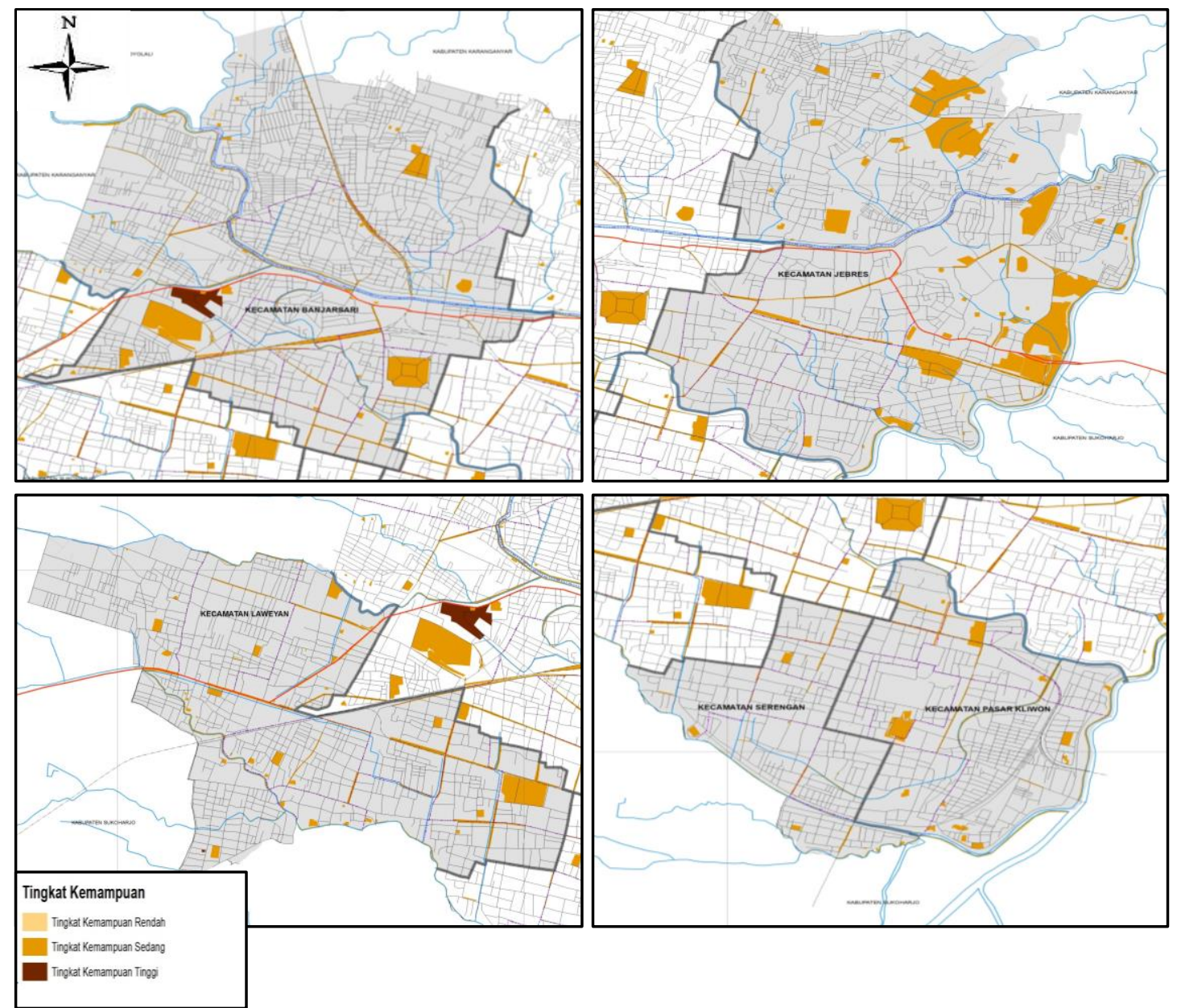

Gambar 3. Persebaran RTH Publik di Surakarta berdasarkan Tingkat Kemampuan Mereduksi Limpasan Air

\section{KESIMPULAN}

Ruang terbuka hijau (RTH) Publik di Surakarta didominasi memiliki tingkat kemampuan sedang dalam mereduksi limpasan air. Jenis ruang terbuka hijau publik di Surakarta terdiri dari Taman RT, Taman RW, Taman Kelurahan, Taman Kecamatan, Taman Kota, Hutan Kota, Sabuk Hijau, Pulau Jalan dan Median Jalan, Jalur Pejalan Kaki, RTH Sempadan Rel Kereta Api, RTH Sempadan Sungai, RTH Pengaman Sumber Air Baku, dan RTH Pemakaman. Luas Ruang Terbuka Hijau Publik di Surakarta sebesar 283 Ha yang terdiri dari 13 jenis. Ruang Terbuka Hijau mampu meresapkan air sebesar $900 \mathrm{~m} 3 / \mathrm{Ha}$ setiap tahunnya. Sehingga dengan luas sebesar $283 \mathrm{Ha}$, Ruang Terbuka Hijau Publik di Surakarta mampu meresapkan air sebesar 254.700 $\mathrm{m} 3 /$ Tahun atau $0.26 \%$ dari volume air hujan di Surakarta. Terdapat 7 kriteria yang digunakan untuk menilai tingkat kemampuan Ruang Terbuka Hijau untuk mereduksi genangan air, yaitu karakteristik kawasan dan tutupan lahan yang berkaitan dengan koefisien limpasan, jenis vegetasi yang berkaitan dengan daya infiltrasi, tekstur tanah yang berkaitan dengan daya infiltrasi dan pergerakan air (perlokasi), jenis tanah yang berkaitan dengan permeabilitas, kelerengan, curah hujan, dan ketersediaan teknologi resapan. Dari hasil skoring yang dilakukan pada 637 unit RTH Publik dengan 7 variabel yang ada, didapatkan hasil 20 unit RTH memiliki tingkat kemampuan rendah dengan luas $8.97 \mathrm{Ha}, 615$ unit RTH dengan tingkat kemampuan sedang dengan luas $271.37 \mathrm{Ha}$, dan 3 unit RTH dengan tingkat kemampuan tinggi dengan luas $2.66 \mathrm{Ha}$. Kapasitas Ruang Terbuka Hijau Publik di Surakarta mampu meresapkan air hujan sebesar 171.522 m3/Tahun atau sebesar $67.34 \%$ dari kapasitas maksimumnya. Keberadaan ruang terbuka hijau publik tersebut tersebar di seluruh wilayah administrasi Kota Surakarta. Dengan kondisi tersebut, maka kemampuan ruang terbuka hijau publik di Surakarta dalam mereduksi genangan air masih harus ditingkatkan. 


\section{DAFTAR PUSTAKA}

Prianggoro, A. A. (2015). Prediksi Tutupan Lahan Terbangun Sebagai Dasar Pengendalian Pemanfaatan Ruang Kawasan Perkotaan Semarang. Urban Studies And Development (p. 2). Semarang: CoUSD Proceedings.

Samsudi. (2010). Ruang Terbuka Hijau Kebutuhan Tata Ruang Perkotaan Kota Surakarta. Journal of Rural and Development, 13-14.

Sarbidi. (2012). Kajian Subreservoir Air Hujan Pada Ruang Terbuka Hijau Dalam Mereduksi Genangan Air (Banjir). Jurnal Permukiman Vol. 7 No. 3 November 2012 : 176-184.

Syamsir, E. (2017). Kajian Kebutuhan dan Penyediaan Ruang Terbuka Hijau Kota Soreang. Fakultas Teknik Unpas.

Resubun, E. (2015). Analisis Pemanfaatan Ruang Pada Kawasan Resapan Air Di Kelurahan Ranomuut Kecamatan Paal Dua Kota Manado. Hidrosfer.

Untari. (2012). Studi Pengaruh Perubahan Tata Guna Lahan Terhadap Debit Di Das Citepus, Kota Bandung.

Wibowo, M. (2006). Model penentuan kawasan resapan air untuk perencanaan tata ruang berwawasan Lingkungan. Journa; Hidrosfir, 3.

Zahrotunisa, S. (2017). Prediksi Spasial Perkembangan Lahan Terbangun. Jurnal Online Informatika, 30. 